\title{
WORLD EXPERIENCE OF PROCESS QUALITY MANAGEMENT OF TEACHER TRAINING IN HEI
}

\author{
Tetyana Kravchenko ${ }^{1}$, Iryna Saienko²
}

\begin{abstract}
The quality of higher education is the main feature of HEl. There are several approaches to assessing the performance of educational institutions. One of the leading process approaches is based on the principles of TQM (Total Quality Management) and the requirements for quality management systems of the International Organization for Standardization ISO. The basis for assessing the quality of higher education and training, as well as the quality of HEl's activities are educational standards. The Ukrainian standards include: state standard, industry standards, HEl's standards. The international standards of ENQA education quality guarantees include: standards for internal quality assurance of $\mathrm{HEl}$, standards for external quality assurance of $\mathrm{HEl}$, the European standards for external agencies of quality assurance. There are several models of education quality management systems: model of quality management system according to the international standard ISO 9001:2000 (DSTU ISO 9001:2001); the model of the European Foundation for Quality Management (EFQM) and its modifications for HE; the model of the Center for Higher Education Policy Studies (CHEPS) of the University of Twente (Netherlands); model of the Association of Universities in the Netherlands (VSNU); Belgian-Dutch model (Expertgroep HBO); Malcolm Baldrige National Quality Award in the field of education; benchmarking model for Australian universities and others. According to most researchers, there are some advantages in creating a quality management system of higher education institution in the context of the TQM ideology, which involves the application of process and systemic principles. The comparative characterization of factors influencing the quality of education in comparison with the principles of TQM, EFQM's criteria and the requirements of the international standard ISO 9001:2000 and interdependent business processes. In the universities of the USA, France, Great Britain and other developed countries, the problems of general process quality management are considered in three planes. The study of the positive experience of developed countries, HEls of which are included in the world rankings, and graduates are in demand in the labor market, allows to form a mechanism for implementing the TQM principles both at the state and regional levels.
\end{abstract}

Key words: process approach, ISO standards, TQM concept, HEl's quality management models, PDCA Deming cycle, EFQM model, education quality.

JEL Classification: I21, I28, V10, L22

\section{Introduction}

The quality of education in a modern environment is crucial for the successful development of any country. Revolutionary changes in technologies based on intellectual resources are becoming the most important factor determining the development of the economy.

The decisive role of HEI is precisely in the development of intellectual resources of the country, which are competitive in the modern labor market, i.e. are able to ensure the implementation of innovative projects in the economy.

The search for modern tools to ensure a high level of quality of educational activities has intensified with increased competition among HEIs. International experience shows that only organizations capable of ensuring world-class product quality and service delivery have achieved leadership. Quality is a priority factor in ensuring the competitiveness of HEIs (Asiyai, 2014).

The Universitas 21, or U21, is the only one ranking in the world to assess national higher education systems and is designed as a benchmark for governments, educational institutions and a variety of individuals. Analyzing the data of the ranking for 2019, which unites 50 countries, we see that in general, Ukraine is in the 39th place and the level of qualification of

\footnotetext{
Corresponding author:

${ }^{1}$ MI “Zaporizhzhia Regional Institute of Continuing Pedagogical Education” ZRC, Ukraine.

E-mail: november74t@gmail.com

${ }^{2}$ Military Academy (Odessa), Ukraine.

E-mail: politlaw@gmail.com

ORCID: https://orcid.org/0000-0002-5623-1022
} 
the workforce occupies the 14th position, while the United States occupies the 18th and 6th positions, respectively, the UK in both positions ranks the 8 th, Japan is at the 20th place overall and ranks the 3rd in terms of qualification quality, France ranks the 18th and the 6th, respectively, Sweden's place is the 2nd in the overall ranking, while the quality level belongs to the 17 th place only, Bulgaria, for example, ranks the 40th in the U21 rankings and the qualification level is at the28th place (U21, 2019).

As we can see, the level of qualification of the workforce in Ukraine, as a product of HEI, is relatively low compared to developed countries, which confirms the need for modern approaches to quality management of HEI as a producer of highly skilled labor.

The quality of educational services provided is determined by such an effective indicator as the quality of higher education. Monitoring the quality of higher education with the use of modern information technologies makes it possible to analyze the current situation and identify the main problems.

\section{Methodology of research}

\subsection{Determining the basic standards of the model of formation of the process quality management system of HEI}

The quality of education is directly associated with the quality of HEI's educational services and the perfection of its quality management system, which is aimed at continuous improvement (Baird, 2006). Most HEIs use the international ISO 9000 series standards (TQM, 2009), improving their quality management systems based on the concepts of total quality management (TQM), which provide continuous improvement of the organization, enhancing the quality of products (services) and meeting the needs of all stakeholders: customers, suppliers, personnel and society.

The approach based on the application of the "Quality Management System" in educational institutions encourages HEIs to analyze customer requirements, identify processes that contribute to the creation and provision of educational services acceptable to the customer, and manage these processes. Implementation of the process approach in the HEI management is one of the main requirements of the Quality Management System (Najm, Najm A., et al., 2017).

According to the analysis of world practice, to create a quality management system in HEI, it is advisable to use universal principles applied in various fields of activity, but adapted to learning activity (TQM, 2012; Aigbomian, 2012; Nwadiani, 2014). That is, the application of international standards of the ISO 9000 series, which are based on the application of TQM principles.

The foundation of this philosophy of quality was laid at the beginning of the last century in the United
States by Frederick Taylor, developed by the American engineer, scientist and philosopher Walter Shewhart in the 1920s (he considered the founder, developer of a control system) and received further development in the works of the American researcher William Deming, Joseph Juran, the Japanese scientists Homer Sarason and Kaoru Ishikawa, etc. (Law of Ukraine of July 1, 2014).

The ideology of TQM is based on a process approach to quality management, which involves constant control on the basis of objective measurement, the joint work of the members as a single team with the involvement of each employee; building a management system based on approved documents governing the operation. When applying TQM principles, it is necessary to identify key processes, manage them and constantly improve them to better the result.

It is important to have a managerial component of the system. It should be noted that educational activity, or rather, the provision of educational services, has certain differences: the long process of providing such services, its complexity (multidisciplinarity), the involvement of a huge number of employees (both academic and others involved in organization of the process of providing educational services), as well as the duration of use of consumers of educational services and their high responsibility (graduates are a major component of the future potential of society) (Nwadiani, 2014). Therefore, using any international standards, it is better to avoid both the application of all requirements without adapting them to the national conditions and characteristics of a particular educational institution, and ignoring the experience gained.

A creative approach to the development of their own provisions with an adequate interpretation of international experience and the existing conditions of the institution is needed.

However, the generally accepted principles of TQM must be used in the development of quality management system of educational institutions. Key principles include (Tricker, 2010; TQM, 2009):

- target orientation of the management on the quality satisfying the consumer, personal participation in performance of the set purposes and creation of conditions for participation of all personnel in activity on increasing the quality;

- systemic managerial influences aimed at improving quality;

- the integral nature of all activities of the organization; - constant and continuous activities to improve results and quality indicators - gradually, but all the time; - decision-making based on the analysis of systematic information, rather than random fragmentary data; - team style of work, including with the participation of partners.

Regarding the concept of "education quality", the modern philosophers and scholars interpret the quality of education as "a social category that determines the 
state and effectiveness of the educational process in society, its compliance with the needs and expectations of society (Lukina, Korzhevskaya, 2007)”, “...the ratio of the learning purpose and outcomes, the degree of its achievement, provided that the purpose is set operationally and predicted in the area of potential development of the student" (Tsarenko, 2015).

Thus, the education quality management is the direction of the regulatory body of its activities to increase the value of the educational process in society within its ability to meet the needs of such a society.

For example, education quality management is recognized as a special management, organized and aimed at achieving not any educational outcomes, not accidental, not just better than the previous ones, but well-defined, predicted in advance with a possible degree of accuracy, where the goal (result) should be predicted operationally in the area of potential graduate development (Armand Faganel and Slavko Dolinšek, 2010).

As we can see, education quality management is a fairly broad concept that can be specified at each of the levels and objects of its management, including primary, secondary, vocational or higher education.

In particular, the Law of Ukraine "On Higher Education" dated July 1, 2014 defines the quality of higher education as the level of acquired knowledge, skills, abilities and other competencies, which reflects its competence in accordance with the standards of higher education (Law of Ukraine of July 1, 2014 "On Higher Education"). Therefore, the evidence of receiving a quality education is the provision of the amount of knowledge, skills, abilities and competencies for the graduate determined by the Ministry of Education and Science.

Thus, the education quality management is the direction of the regulatory body of its activities to increase the value of the educational process in society within its ability to meet the needs of such a society.

For example, George S., Weimerskirch A. (2009) recognize education quality management as a special management, organized and aimed at achieving not any educational outcomes, not accidental, not just better than the previous ones, but well-defined, predicted in advance with a possible degree of accuracy, where the goal (result) should be predicted operationally in the area of potential graduate development.

As we can see, education quality management is a fairly broad concept that can be specified at each of the levels and objects of its management, including primary, secondary, vocational or higher education.

In accordance with para. 23 of Art. 1 of the Law of Ukraine "On Higher Education" dated July 1, 2014, the quality of higher education is the level of acquired knowledge, skills, abilities and other competencies, which reflects its competence in accordance with the standards of higher education ((Law of Ukraine of
July 1, 2014 "On Higher Education"). Hence, the evidence of receiving a quality education is the provision of the amount of knowledge, skills, abilities and competencies for the graduate determined by the Ministry of Education and Science.

Undoubtedly, the key factor in choosing the future strategy of the HEI in the field of quality is the current level of institutionalization of its quality system based on different quality models (TQM, ISO standards, ENQA, EFQM, etc.). It should be noted that the principles, on which the above models are based, in the vast majority coincide, and if they differ, it is possible only in the degree of coverage of the completeness and depth of the main and resource processes in the organization.

Analysis of scientific sources on the quality of higher education shows that in the world, there are the following models of higher education quality management (Silonova, Sidliarenko, 2015):

- Quality management of higher education based on ISO 9001 standards;

- Quality management of higher education based on TQM principles;

- Model of the European Foundation for Quality Management (EFQM);

- Model of the Center for Higher Education Policy Studies at the University of Tverte (the Netherlands) CHEPS;

- Association of Universities in the Netherlands (VSNU);

- Belgian-Dutch model (Expertgroep HBO);

- Model of the Malcolm Baldrige National Quality Award in the field of education;

- Benchmarking model for Australian universities.

In our opinion, the fundamental methodological basis for the application of most modern models of quality of higher education is the methodology of total quality management (TQM). The process approach, consumer orientation are the cornerstones of TQM, which have been further developed in quality models based on the international standards of the ISO series.

Since the principles of another European model ENQA - are focused only on higher education levels and do not extend to other areas, including research, general management of educational institutions, it is advisable to use them as a supplement to the basic model (Zaggl, 2017).

\section{Results and discussion}

\subsection{Strategic priorities of formation and development of the HEI's process quality management system}

The most widely used quality management system is the system that meets the ISO 9000 standard (latest version of 2001 - ISO 9001:2000), which is recognized worldwide as the most effective, flexible, 
optimally documented. This system was started in 1979 in Great Britain and was later adapted to the sector of education in Europe and many other countries (Law of Ukraine of July 1, 2014). The requirements of the ISO 9001:2000 standard do not apply to the structure and content of scientific research, it does not operate in the classroom, where the teacher enjoys the academic freedom given to him or her to realize his or her scientific and methodological potential (Baird, 2006).

As practice shows, one of the most common approaches to quality management of higher education services is the model of Total Quality Management (TQM), which involves all staff in creating high quality products or services at all stages of its life cycle from stages of marketing, design, production, operation, maintenance to disposal (Silva, Miranda, Gomes, Paulo, Luís and Zulema, 2014).

The TQM model assumes the presence of a clear mission in the higher education institution, strategic goals, which are formed as a result of a comprehensive study of the needs of the external environment (the needs of society, the region, etc.). The TQM quality management model is also called universal quality management, because it provides a process approach to the activities of higher education institutions and uses effective methods and tools of quality management (Plysenko, 2016).

Every organization needs continuous improvement in order to maintain the existing and achieve newer advantages over competing organizations. One of the methods of continuous improvement is the management of the organization according to the well-known Deming cycle PDCA - Plan, Do, Check, Act. PDCA methodology is a simple algorithm of actions of the head to manage the process and achieve its goals and is applicable to all the above processes of the quality management system of HEI (Lukina, Korzhevskaya, 2007).

The introduction of a process approach to the management of HEI makes it possible to use resources rationally to ensure the HEI's viability and to ensure transparency regarding accountability, decisionmaking, etc. The peculiarities of the process approach are the purposefulness of any action and process for the end result: meeting the requirements of consumers, compliance with the law, as well as with the requirements established within HEI.

The concept of quality of TQM is based on the following principles:

- involvement of top management and all personnel;

- consumer orientation;

- process and systemic approach;

- constant quality improvement;

- fact-based decision-making;

- establishing partnership with suppliers.

In more detail, the basic principles of quality management for higher education in accordance with TQM are as follows (Figure 1).
In the universities of the USA, France, Great Britain and other developed countries, the problems of general process quality management are considered in three planes:

1. Teaching TQM as an independent discipline in the learning process both in HEI and in the process of postgraduate training.

2. Organization of teaching other disciplines using the TQM principles and methods.

3. Organization of HEI's management based on the TQM principles and methods.

Getting acquainted with TQM begins with a review of the quality concept evolution according to four concepts of quality: compliance with the standard; compliance with use; compliance with costs; compliance with hidden requirements (August-Wilhelm, 2000).

In general, the TQM methodology has been used in higher education since the early 1990s (George, Weimerskirch, 2009). The positive implementation of the TQM principles in the activities of HEIs in developed and developing countries has resulted in increased student performance, improved curriculum quality, improved involvement of the academic staff and personnel of HEI in advancing the quality of demand for graduates (Bologna process, 2000).

\subsection{Determining the benefits of using different models of HEI's management in the context of the process approach}

According to most researchers, there are some advantages in creating a quality management system of higher education institution in the context of the TQM ideology, which involves the application of process and systemic principles.

In this connection, the system approach is based on the paradigm of quality management, focused on the concept of interconnections and interactions, which is considered as a set of interdependent elements of the external environment and internal structure of the enterprise.

The advantage of the process approach is to ensure continuous monitoring of the links of individual processes within a system of interconnected and interdependent business processes, based on the implementation of the requirements of the standard ISO 9000:2000 (Using PDSA, 2017).

The application of DSTU and ISO 9001:2000 to create a quality management system for the provision of educational services is not a one-time campaign, but a significant and complex innovation. The creation of a quality management system for the task, which sometimes requires non-traditional approaches to its solution involving compliance with the principles of systematization, should take place through the implementation of the objectives of interrelated stages. This requires following certain sequence: 


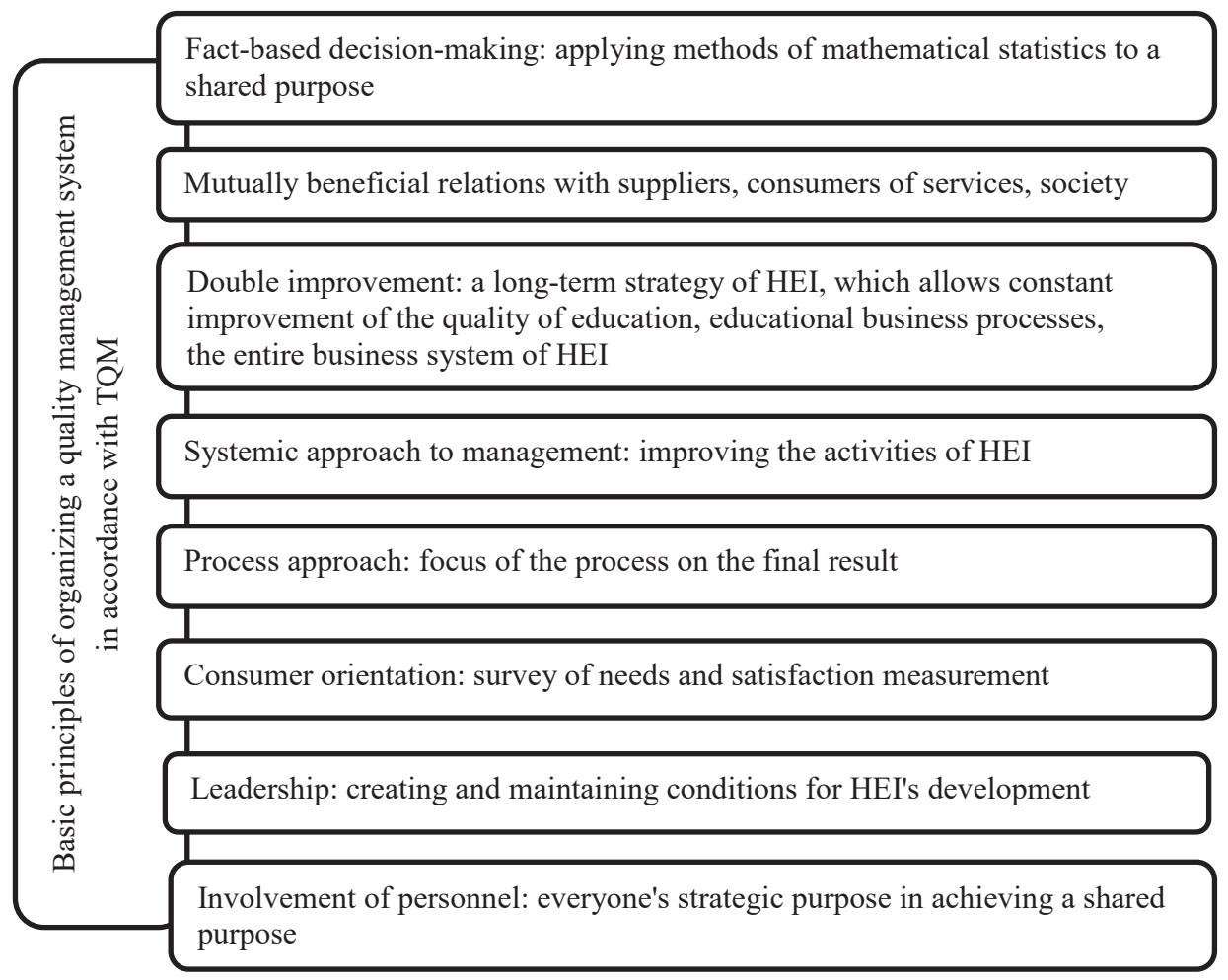

Figure 1. Basic principles of organizing a quality management system according to the TQM concept Source: compiled on the basis of (George, Weimerskirch, 2009; Tsarenko, 2015)

1. Creating a team to form a quality policy and a description of the main processes in HEI.

2. Training and motivation of the institution's personnel, training of quality representatives, managers and auditors. It is important that the employees are aware of their role, responsibilities and authority within the quality management system. A prerequisite is the involvement of students as the main consumers of educational services.

3. Development (design) of a system that allows you to manage processes, actions and tasks at all levels effectively.

4. Development of an internal audit system that will assess the readiness degree of structural units of universities to work well, in accordance with the requirements of DSTU and ISO 9001:2000.

5. Introduction of a quality management system for the provision of educational services.

One of the main tasks of the third, fourth and fifth stages of the proposed sequence is to create a documentation package governing the implementation of all processes in the quality management system of educational services.

Modern approaches to the creation or modernization of the quality management system of educational services impose each educational institution to create such documents as (EFQM Model criteria, 2014).

1. ECTS information package.

2. Documented quality policies and objectives.

3. Quality manual.
4. Documented methods required by DSTU ISO 9001:2000, which set out the policies, objectives, mechanisms and criteria for the quality of educational services and methods used for this purpose.

Another common approach to managing the quality of higher education services is the introduction of the European Foundation for Quality Management (EFQM) criteria. They are based on nine main criteria (Figure 2) (Model criteria. EFQM, 2014).

Five of these criteria are "Opportunities", and the other four are "Results". "Opportunities" criteria characterize the potential of the organization, and "Results" are for the outcomes achieved (Model criteria. EFQM, 2014).

The model of the European Foundation for Quality Management in higher education was developed by Sheffield Hallam University in Great Britain. Among the main advantages of the model for higher education, there are the following: understanding and anticipation of students' needs and expectations, demonstration of forward-looking leadership; involvement of employees; development of mutually beneficial relations, etc. (Armand Faganel and Slavko Dolinšek, 2010).

The list of factors influencing the quality of education in comparison with the TQM principles, EFQM criteria and the requirements of the international standard ISO 9001 mentioned in Table 1 gives grounds to conclude that these factors are fully embedded in the common ideology of TQM, on which they are based (Armand Faganel and Slavko Dolinšek, 2010). 


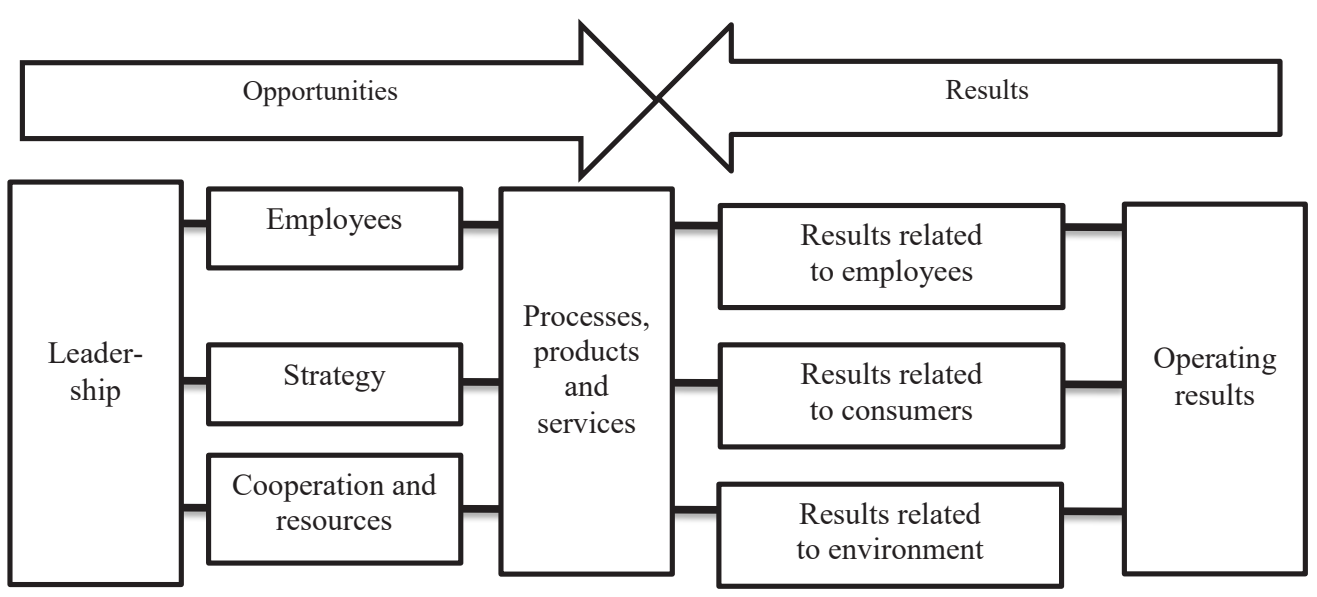

Figure 2. Model of the European Foundation for Quality Management (EFQM)

Source: (Model criteria. EFQM, 2014)

Thus, the current state of quality of higher education is a matter of concern, which leads to the need to manage the quality of educational services provided by domestic HEIs.

The study of positive experience of developed countries, whose HEIs are included in the world rankings, and graduates are in demand in the labor market to implement the principles of General Quality Management, in accordance with the quality system ISO 9001:2000, allows to state the need for these approaches to be implemented by the Ukrainian HEIs to increase the competitiveness of graduates in the labor market in both national and international contexts. As a result, the state regulation should form a clear mechanism for implementing the principles of Total Quality Management (TQM) in the activities of HEIs, create a consulting committee on the implementation of approaches to quality management in education at the Ministry of Education and Science, promote the exchange of positive experience with foreign HEIs through holding roundtable meetings, conferences and seminars at the state level, which as a result, will allow leaders of the Ukrainian universities to learn from foreign experience in strengthening the competitive position of their graduates in the labor market.

\section{Conclusions}

Creating quality management systems requires educational institutions to attract significant financial and human resources, which the educational institution cannot always afford. In addition, the result of the implementation of such systems will become apparent only in a few years. Therefore, the state can and should initiate and stimulate the development of the process of development and implementation of such HEIs' systems.

In most HEIs in Europe and other regions, to form a quality management system the basic international standard ISO 9001:2000 is used to improve their quality management systems based on the concepts of total quality management (TQM), which provide for continuous transformation of the organization, modifying the quality of products (services) and meeting the needs of all key parties.

The defined principles of TQM are generally accepted, and must be used in the development of quality management system of educational institutions. The process approach, consumer orientation are the cornerstones of TQM, which have been further developed in quality models based on international standards of the ISO series.

The most widely used quality management system is the system that meets the ISO 9000 standard (latest version of 2001 - ISO 9001:2000), which is recognized worldwide as the most effective, flexible, and optimally documented.

The TQM model assumes the that the HEI has a clear mission, strategic goals, which are formed as a result of a comprehensive study of the needs of the external environment (the needs of society, the region, etc.).

In the universities of the USA, France, Great Britain and other developed countries, the problems of general process quality management are considered in three planes: 1. Teaching TQM as an independent discipline in the learning process both in HEI and in the process of postgraduate training. 2. Organization of teaching other disciplines using the TQM principles and methods. 3. Organization of HEI's management based on the TQM principles and methods.

The advantage of the process approach is to ensure continuous monitoring of the links of individual processes within a system of interconnected and interdependent business processes, based on the implementation of the requirements of the standard ISO 9000:2000.

The list of factors influencing the quality of education in comparison with the principles of TQM, EFQM criteria and the requirements of the international standard ISO 9001 presented in Table 1 gives grounds 
Table 1

Comparative characteristics of education quality management models in terms of factors influencing the quality of training in HEI

\begin{tabular}{|c|c|c|c|c|}
\hline No. & $\begin{array}{l}\text { Factors influencing the quality } \\
\text { of training in HEI }\end{array}$ & TQM principles & EFQM criteria & $\begin{array}{l}\text { ISO 9001:2000 } \\
\text { requirements }\end{array}$ \\
\hline & Training level of entrants & $\begin{array}{l}\text { Consumer orientation. } \\
\text { Establishing mutually } \\
\text { beneficial relationships } \\
\text { with suppliers. }\end{array}$ & $\begin{array}{l}\text { Use of the potential of } \\
\text { employees. }\end{array}$ & $\begin{array}{l}\text { 7.3.2. Design and development } \\
\text { inputs }\end{array}$ \\
\hline & $\begin{array}{l}\text { The level of teacher preparation, } \\
\text { recruitment, training, level of social } \\
\text { protection }\end{array}$ & $\begin{array}{l}\text { The role of top } \\
\text { management. } \\
\text { Involvement of personnel }\end{array}$ & $\begin{array}{l}\text { The role of top management. } \\
\text { Policy and strategy. } \\
\text { Satisfaction of the personnel. }\end{array}$ & 6.2. Human resources \\
\hline & $\begin{array}{l}\text { Organization of the educational process, } \\
\text { introduction of scientific achievements } \\
\text { into the educational process }\end{array}$ & Process approach & Process management & $\begin{array}{l}\text { 7.3.2 Design and development inputs } \\
\text { 7.5. Production and service } \\
\text { provision }\end{array}$ \\
\hline & $\begin{array}{l}\text { Equipping with training equipment, } \\
\text { textbooks, manuals, computers and } \\
\text { office equipment, use of information } \\
\text { technology }\end{array}$ & Systemic approach & Rational use of resources & $\begin{array}{l}\text { 6.3. Infrastructure } 6.4 \text {. Work } \\
\text { environment }\end{array}$ \\
\hline & $\begin{array}{l}\text { Humanitarization of education, } \\
\text { extracurricular educational work }\end{array}$ & Process approach & Process management & $\begin{array}{l}\text { 7.3.3. Design and development } \\
\text { outputs }\end{array}$ \\
\hline & $\begin{array}{l}\text { Organization of student's individual } \\
\text { work }\end{array}$ & Involvement of personnel & $\begin{array}{l}\text { Use of the potential of } \\
\text { employees }\end{array}$ & $\begin{array}{l}\text { 7.5. Production and service } \\
\text { provision }\end{array}$ \\
\hline & $\begin{array}{l}\text { Motivation of students to quality } \\
\text { education }\end{array}$ & Involvement of personnel & $\begin{array}{l}\text { Use of the potential of } \\
\text { employees }\end{array}$ & $\begin{array}{l}\text { 7.5. Production and service } \\
\text { provision }\end{array}$ \\
\hline & $\begin{array}{l}\text { Motivation of students to quality } \\
\text { education }\end{array}$ & Involvement of personnel & Consumer satisfaction & $\begin{array}{l}\text { 7.3.3. Design and development } \\
\text { outputs }\end{array}$ \\
\hline & $\begin{array}{l}\text { Control of students' knowledge, skills } \\
\text { and abilities }\end{array}$ & $\begin{array}{l}\text { Fact-based decision- } \\
\text { making }\end{array}$ & $\begin{array}{l}\text { Process management. } \\
\text { Results. }\end{array}$ & $\begin{array}{l}\text { 8.2.4. Monitoring and } \\
\text { measurement of product } \\
\text { 8.3. Control of nonconforming } \\
\text { product }\end{array}$ \\
\hline & $\begin{array}{l}\text { Assessment of the level of student } \\
\text { training by employers, society }\end{array}$ & Consumer orientation & $\begin{array}{l}\text { Satisfaction of consumers } \\
\text { and society } \\
\text { Results }\end{array}$ & 8.2.1. Customer satisfaction \\
\hline & Level of self-esteem and improvement & Continual improvement & Results & $\begin{array}{l}\text { 8.2.2. Internal audit } \\
\text { 8.4. Analysis of data } \\
\text { 8.5. Improvement }\end{array}$ \\
\hline & $\begin{array}{l}\text { Level of compliance with state } \\
\text { accreditation requirements }\end{array}$ & Consumer orientation & $\begin{array}{l}\text { Satisfaction of consumers } \\
\text { and society } \\
\text { Results }\end{array}$ & 1.1. General provisions \\
\hline & $\begin{array}{l}\text { Communication with employers and } \\
\text { alumni }\end{array}$ & Consumer orientation & $\begin{array}{l}\text { Satisfaction of consumers } \\
\text { and society } \\
\text { Results }\end{array}$ & $\begin{array}{l}\text { 7.2. Customer-related processes } \\
\text { 7.2.3. Customer communication }\end{array}$ \\
\hline & Organization of continuing education & Continual improvement & $\begin{array}{l}\text { Process management } \\
\text { Results }\end{array}$ & $\begin{array}{l}\text { 8. Measurement, analysis and } \\
\text { improvement }\end{array}$ \\
\hline
\end{tabular}

Source: (Tsarenko, 2015)

to conclude that these factors are fully embedded in the common ideology of TQM, on which they are based.

Since the quality management system is implicitly related to the quality of HEI, it is indirectly characterized by the next stage of research: the result of self-assessment of the level of development and implementation of quality management system of HEI. Given the adequate and interconnected formulation of goals and tools of these two studies, it is possible to establish a relationship between the level of satisfaction of end users (students of $\mathrm{HEI}$ ) and the assessment of the developed and implemented quality management system of HEI in the form of business process maturity.

The use of modern information technologies in the field of education allows for more effective quality monitoring. Information technology is not so much a tool that complements the higher education system, but an imperative to establish a new order of knowledge and its institutional structures. The purpose of the national system for monitoring the quality of education is to provide society with reliable data on the state of the education system for accountability, effective functioning and improving. 


\section{References:}

Asiyai, R. I. (2014). Challenges of quality higher education in Nigeria in the 21 st century. International Journal of Educational Planning and Administration, vol. 3, no. 2, pp. 159-172.

Aigbomian, D. O. (2012). Quality education for transformation of individual and national values. Paper presented at the International Conference of the Faculty of Education, Delta State University, Abraka. November 14.

Armand Faganel and Slavko Dolinšek (2010). Quality Management Systems in Higher Education.

August-Wilhelm, S. (2000). Modeling of business processes / trans. from English O. N. Mikhailov. Moscow: Silver Threads LLC.

Baird, J. R. (2006). Quality: what should make higher education "higher"? Higher Education Research and Development, vol. 7(2), pp. 141-152. doi: http://dx.doi.org/10.1080/0729436880070205

Bologna process (2000). Bologna process : state, problems, ways of realization. Bureau of European Education. Available at: http://euroosvita.ospua.info/html/ch2/epvo.html

George, S., \& Weimerskirch, A. (2009). TQM. Total quality management. SPb. House of Science.

Law of Ukraine of July 1 (2014). № 1556-VII “On Higher Education”. Available at: http://zakon4.rada.gov.ua/ laws/show/1556-18

Lukina, T. O., \& Korzhevskaya, G. M. (2007). Development and implementation of an education quality management system in the system of professional training of civil servants. Available at: https://core.ac.uk/ download/pdf/32304887.pdf

Model criteria. EFQM (2014). Available at: http://www.efqm.org/efqm—model/model-criteria

Plysenko, G. (2016). Use of information technology in monitoring the quality of higher education under integrative system of competitive advantages application: theoretical and methodological aspects. Bulletin KNUTD, vol. 2(97), pp. 71-78.

Nwadiani, M. (2014). Education and transformation leadership in a tertiary learning environment: Professor O. G. Oshodin in perspective. Sixth Faculty of Education Lecture Series, University of Benin, Benin-City, April, 30. Najm, Najm A., Yousif, A.S. H. \& Al-Ensour, Jasser A. Al-Ensour (2017). Total quality management (TQM), organizational characteristics and competitive advantage. ournal of Economic \& Financial Studies. August 5(04):12. Satish, K. P., \& Srinivasan, R. (2010). Total quality Management and Innovation performance: An Empirical Study on the interrelationships and Effects. South Asian Journal of Management, vol. 17(3), pp. 8-22.

Silva, G. Miranda, Gomes, Paulo J. L., Luís F., \& Zulema L. P. (2014). The role of TQM in Strategic Product Innovation: An Empirical Assessment. International Journal of Operations \& Production Management, vol. 34(10), pp. 1307-1337. doi: https://doi.org/10.1108/IJOPM-03-2012-0098

Silonova, N. B., \& Sidliarenko, A. V. (2015). Analysis Of Modern Management Systems To Improve The Educational Process In Universities. Scientific researches and their practical application. Modern state and ways of development. № 6-18.

TQM (2012). TQM as a management strategy for the next millennia. International Journal of Operations \& Production Management, vol. 21 (5/6), pp. 855-876. doi: https://doi.org/10.1108/01443570110390534

Tornow, W. W., \& Wiley, J. W. (1991). Service Quality and Management Practices. Human Resources Planning, vol. 14(2), pp. 105-15.

Tsarenko, I. O. (2015). Foreign experience in quality management of educational services in higher education. XI International Conference "Quality Strategy in Industry and Education". June 1-5, 2015, Technical University of Varna (Bulgaria), pp. 289-297.

Tricker, R. (2010). ISO 9001: 2008 for Small Businesses, Oxford: Elsevier Ltd.

TQM (2009). Quality management systems (2009). Requirements (ISO 9001: 2008, IDT): DSTU ISO 9001 : 2009. [Effective from 2009-09-01]. Kyiv: Derzhspozhyvstandart of Ukraine.

Using PDSA (2017). Using PDSA to improve the quality of learning. Available at: http://agrostandart.com/ yakist/30-osoblyvosti-zastosuvannia-protsesnoho-pidkhodu-pry-rozrobtsi-systemy-upravlinnia-iakistiuvyshchoho-navchalnoho-zakladu

U21 (2019). Ranking of National Higher Education Systems. Available at: http://www.universitas21.com/article/ projects/details/152/u21-ranking-of-national-higher-education-systems

Zaggl, A. (2017). Manipulation of explicit reputation in innovation and knowledge exchange communities: The example of referencing in science. 